\title{
THE AMENDMENT TO THE LAW REFORM (MARRIAGE AND DIVORCE) ACT 1976: RECONCILING THE IRRECONCILABLE*
}

\author{
Najibah Mohd Zin* \\ Nora Abdul Hak** \\ Abdul Ghafur*** \\ Hidayati Mohamed Jani ${ }^{* * * *}$
}

\begin{abstract}
This article examines the ramifications of the 2017 amendment to the Law Reform (Marriage and Divorce) Act 1976 (Act 164) in protecting the wellbeing of the family relationship involving interfaith marriage and other legal issues governing non-Muslim families. The amendment witnessed substantial reforms to section 51 of Act 164 pertaining to the divorce on the ground of conversion, increasing the age limit for child maintenance and adopting more flexible principles in dividing matrimonial assets. However, the focus will be on the impact of the amendment to section 51 of Act 164 due to its significance in changing the landscape of legal arguments pertaining to jurisdiction of the court in dealing with the subject matter in dispute, ranging from the divorce and other intense arguments pertaining to maintenance of wife, child custody and religious status of children. The study adopts a qualitative study in elucidating relevant documents that comprised of statutory laws, articles in legal journals and decided cases where arguments leading to the need for the reform of those affected issues were well addressed. Certain aspects of Islamic jurisprudence will be referred to and analysed in
\end{abstract}

* Professor, Department of Islamic Law, Ahmad Ibrahim Kulliyyah of Laws, International Islamic University of Malaysia. Email: najibah@iium.edu.my.

** Professor, Department of Islamic Law, Ahmad Ibrahim Kulliyyah of Laws, International Islamic University of Malaysia. Email: ahnora@iium.edu.my.

*** Professor, Department of Civil Law, Ahmad Ibrahim Kulliyyah of Laws, International Islamic University of Malaysia. Email: ghafur@iium.edu.my

**** PhD Candidate, Ahmad Ibrahim Kulliyyah of Laws, International Islamic University of Malaysia. 
searching for authoritative and practical legal arguments within the existing legal framework. Harmonisation of law is adopted whenever applicable when dealing with the resolution of conflict of laws. It is hoped that this study will provide constructive arguments acts as an invaluable source of reference for the Malaysian civil court in disposing of interfaith family disputes now that the law is fully enforced.

Keywords: family law conflict, law reform, harmonization of law

\title{
PINDAAN PADA AKTA MEMPERBAHARUI UNDANG- UNDANG (PERKAHWINAN DAN PERCERAIAN) 1976: MEMPERSETUJUI APA YANG TIDAK DAPAT DIPERSETUJUI
}

\begin{abstract}
ABSTRAK
Artikel ini meneliti kesan dari perubahan terhadap Akta Memperbaharui Undang-Undang (Perkahwinan dan Perceraian) 1976 (Akta 164) yang telah terjadi pada tahun 2017, dalam melindungi kesejahteraan hubungan keluarga yang melibatkan perkahwinan antara agama dan masalah undang-undang lain yang melibatkan undang-undang keluarga bukan Islam. Pindaan tersebut menyaksikan pembaharuan yang besar terhadap seksyen 51, Akta 164 yang berkaitan dengan perceraian dengan alasan penukaran agama, meningkatkan had umur untuk nafkah anak dan menerapkan prinsip yang lebih fleksibel dalam membahagikan aset perkahwinan. Akan tetapi, fokus akan diberikan pada impak pindaan pada seksyen 51, Akta 164 kerana perubahannya yang signifikan dalam mengubah landskap argumen hukum yang berkaitan dengan bidang kuasa pengadilan dalam menangani masalah yang melibatkan perceraian dan lain-lain hujah yang berkaitan dengan pemeliharaan isteri, hak penjagaan anak dan status agama anak-anak. Kajian ini menggunakan kaedah kajian kualitatif dalam menjelaskan dokumen-dokumen yang relevan yang terdiri dari akta, artikel dalam jurnal undang-undang dan kes-kes yang diputuskan di mana hujah-hujah yang membawa kepada perlunya pembaharuan terhadap penyelesaian isu-isu yang terjejas agar ianya ditangani dengan baik. Aspek perundangan Islam tertentu akan dirujuk dan dianalisa dalam mencari hujah perundangan yang berwibawa dan praktikal dalam kerangka perundangan yang ada. Kaedah penharmonian undang-undang adalah disarankan dalam mencari penyelesaian konflik undang-undang. Diharapkan kajian ini dapat memberikan hujah yang membina dan sumber rujukan yang tidak ternilai bagi pengadilan sivil Malaysia dalam menyelesaikan pertikaian
\end{abstract}


keluarga antara agama kerana undang-undang telah pun dikuatkuasakan sepenuhnya.

Kata kunci: konflik undang-undang keluarga, pembaharuan undangundang, harmonisasi undang-undang.

\section{INTRODUCTION}

The 2017 amendment to the Law Reform (Marriage and Divorce) Act 1976 (the LRA) involves amendments to several provisions of the Act and this has received requited attention of the Malaysian non-Muslim community for a long time, especially relating to the issue of conversion of one of the parties in a non-Muslim marriage to Islam. By virtue of the amendment, turmoil on the conversion of one party in the non-Muslim marriage finally has been resolved when the law regarding jurisdiction to hear applications for dissolution of marriage involving parties of different religion has been vested in the civil courts. Subsequently, this has put to an end the issue of conflict of jurisdiction between civil and Syariah courts in such matters. Besides amending several provisions relating to religious conversion, the LRA also amends the provisions on the age limit of a child who is entitled to obtain maintenance from the father. Improvement was also seen in the issue of matrimonial assets by giving greater recognition to the concept of contributions, which are the main factors in determining the division of assets and properties of the marriage.

\section{AMENDMENT TO SECTIONS 3 AND 51 RELATING TO CONVERSION AS A GROUND FOR DIVORCE}

Amendments were made to section 3 of the LRA, since the scope of the provision is limited to non-Muslims only and this section shall not apply to those who have converted to Islam. This interpretation has been decided in the case of Letchumy v. Ramadason ${ }^{l}$ where the wife made an application to the court to dissolve the marriage on the ground of desertion by the husband for a constant period of time. ${ }^{2}$ After getting a decree nisi, the wife made a claim to alimony and the matter was then brought to the Judicial Commissioner for decision. The husband subsequently applied to set aside the wife's claim on the ground that he had converted to Islam and therefore the the LRA is not applicable to

[1984] 1 MLJ 143.

2 See the Law Reform (Marriage and Divorce) Act 1976, S.54(1)(c). 
him. For that reason, the Court rejected the application of his wife on the basis that section 3 (3) of the LRA does not apply to Muslims (including those who had converted to Islam). Moreover, the dissolution of marriage, in this case, is not caused by reason of the conversion to Islam but on the ground of desertion, which apparently, falls under the ambit of section 53 of the LRA. As a result, the jurisdiction which is conferred to the Court to make a maintenance order as provided in section 51 (2) of the LRA 1976 does not apply in this case.

The above decision has spawned a variety of reactions and some legal practitioners are questioning whether the conversion to Islam can be used as an excuse to evade from liabilities and responsibilities, which are created before the conversion. ${ }^{3}$ The same questions were submitted in the case of Tang Soon Mooi v. Too Miew Kim ${ }^{4}$ where the wife petitioned to dissolve the marriage after they have not lived together for more than six years. ${ }^{5}$ The High Court of Kuala Lumpur made a decision to dissolve the marriage and within the period of three months before the decree nisi becoming absolute, the wife has made an application against the respondent to obtain an order on the division of the matrimonial properties and maintenance as being provided in section 76 and 77 of the LRA.

The respondent (husband) put an argument that the High Court had no jurisdiction to make an order against him relating to other matters ancillary to the divorce since he had converted to Islam. If the argument is accepted, then the respondent's wife, in this case, would not have any remedy in law because she was not under the jurisdiction of the Syariah Court and thus, could not make any claim against her husband under the Syariah law. For that reason, the wife has questioned section 3(3) of the LRA as unconstitutional since it prevents the High Court from making an order. The conflict was then referred to the Supreme Court for clarification. The Supreme Court in its

3 Muhammad Altaf Hussain Ahangar, "Effects of Change of Religion on Marriage and Maintenance Obligation: Judicial Responses in Malaysia," Paper presented at the Public Lecture, Kulliyyah of Laws, International Islamic University Malaysia on $10^{\text {th }}$ October 1995.

4 [1994] 3 MLJ 117.

5 The said reason is stated in s.53 of the Law Reform (Marriage and Divorce) Act 1976. 
decision pointed out that the High Court has jurisdiction to hear the claim due to the fact that dissolution of the marriage between the parties occurred before the other party convert to Islam. Furthermore, the ancillary reliefs which are provided for under section 51(2) of the LRA were intended to provide reliefs to the non-Muslim spouse and their children in a case where one party to the non-Muslim marriage converted to Islam. The Supreme Court also stressed on the importance of giving the High Court jurisdiction in such matter because otherwise, it would cause an injustice to the non-Muslim party as they could not refer their case to the Syariah court which in its nature only has jurisdiction against parties who are Muslims.

Apparently, the above approach was not conflict with article 121(1A) of the Federal Constitution, which limits the jurisdiction of the High Court in matters involving Islamic law in Malaysia. ${ }^{6}$ Moreover, section 24 of the Courts of Judicature Act 1964 also gives the jurisdiction to the High Court in all other matters including matters pertaining to the dissolution of marriage. The above decision also showed that the validity of the marriage between the plaintiff and the defendant would not be affected by the conversion of one party and it shall be regarded as a valid marriage as long as there is no petition for dissolution of marriage made by the parties who did not convert to Islam.

It is obvious that the amendment to section 3 of the LRA was made with an intention to expand the power of court to hear the divorce applications involving conversion either the petition is made under the provision of section 51 or other provisions aiming to dissolve the marriage such as divorce by mutual consent under section 52 or sections 53 and 54 on the ground of irretrievable breakdown of the marriage. The amendments also allow the civil courts to hear and decide other claims ancillary to the divorce such as division of matrimonial assets, maintenance as well as custody and guardianship of children.

In conjunction with the amendment to section 3 of Act 164, an amendment is also made to section 51. The amendment of this provision is the most awaited and required amendment in resolving the issue of jurisdictional conflict between civil and the Syariah courts

6 
particularly in matters pertaining to the conversion of one party to a non-Muslim marriage to Islam. ${ }^{7}$ By virtue of the amendment, it gives right to both parties either the converting party or the non-converting spouse to submit a petition for divorce under any reasonable provisions. This includes a petition under section 51 on the ground of conversion in which case a petition can be made after the period of three months from the date of the conversion to Islam. Applicants can also make a petition for divorce through mutual consent under section 52 and the irretrievable breakdown of marriage under section 53 where applications can only be made after two years of marriage.

The above amendment is intended to provide an opportunity for either party, and not only the non-converting party, to make a petition for divorce after three months from the date of conversion to Islam. The arguments presented are based on the fact that when a party converted to Islam, there is a clear evidence to show that the marriage had been irretrievably broken down which cannot be recovered again as had been argued in the case of Tey Siew Choo v. Teo Eng Hua ${ }^{8}$ where petition for divorce has been made in accordance with section 54 (1) (d) of the LRA. This is also based on the cases that have been discussed previously ${ }^{9}$ where both parties were not living together because of different beliefs and their way of life. Therefore, it is very important for the law to be amended to allow both conflicting parties to make a petition for divorce and other claims. This is not only to provide justice to both parties who are in conflict, but more importantly it can solve the issue of conflicts of jurisdiction between civil and Syariah courts which has existed for a long period of time.

Undoubtedly, a conflict that arises because of the conversion is a serious issue especially in respect of the marital status of the parties and when making a claim on other matters ancillary to the divorce.

7 See Ahmad Ibrahim, "Dissolution on ground of conversion to Islam," Paper presented at the Conference on Reform of the Law Reform (Marriage and Divorce) Act 1976, at International Islamic University Malaysia, 2-4 December 1992, p.12. This paper was published in Malaysian Law News, March 1993, pp. 29-34.

8 [1999] 6 CLJ 308.

$9 \quad$ Pedley v. Majlis Ugama Islam Pulau Pinang \& Anor [1990] 2 MLJ 307; Ng Siew Pian lwn. Abdul Wahid bin Abu Hassan, Kadi Daerah Bukit Mertajam \& Satu yang lain [1992] 2 MLJ 425. 
Prior to the amendment, the absence of remedies to the converting party under the LRA was non-existent, in the sense that the party converting to Islam does not have any right to make a petition for divorce. This seems to make the conversion as a penalty or punishment on those who convert to Islam. Even though the issue of biasness had been voiced out in Parliament at one point during the debate on the Bill to the amendement of the LRA, there was no effort to address this problem before the approval and enforcement of Act 164 in 1982. Generally, the conflict which has arisen in this issue, is due to the absence of laws that clearly covers the right of both parties in the marriage. This ambiguity has led to a wide range of interpretation of law especially relating to the jurisdiction of the Syariah Court. This situation made it clear that there was an urgency to amend the current law because it not only involves the determination of marital status but also other claims relating to the dissolution of marriage.

The conflict, had also giben rise to the determination of the right of custody and guardianship of children of the marriage. Normally, the main issue in the case of custody disputes involving parents of a different religion is to determine the religious upbringing of the child after their divorce. This has been set out clearly in the decision of the Federal Court in the case of Subashini Rajasingam $v$ Saravanan Thangathoray \& Other Appeals ${ }^{10}$ where the court held that the civil courts have exclusive jurisdiction in determining the status of the nonMuslim marriage and other ancillary matters even if one of the parties had converted to Islam. Therefore, the amendment to section 51(1) of Act 164 was crucial in order to ensure that the civil court is granted with an exclusive jurisdiction to hear all matters relating to the civil marriage and in addition, Article 121 (1A) of the Constitution should be further clarified.

In the case of Indira Gandhi a/p Mutho $v$ Patmanathan a/l Krishnan (anyone Having and Control Over Prasana Diksa) ${ }^{11}$ the Ipoh High Court decided that based on section 3(3) of the LRA, it can be understood that the provision does not apply to Muslims who cannot contract their marriage under Act 164, however, at the same time, it does not mean that this Act does not apply to the party who had contracted their marriage under Act 164 but later converted to Islam. If

\footnotetext{
10 [2008] 2 MLJ 147.

11 [2014] MLJU 547.
} 
section 3(3) is to be interpreted otherwise, it will lead to an inconsistency with section 51 in which the civil court has jurisdiction to grant the order of child custody even if one of the parties to the civil marriage had converted to Islam. Thus, it is clear that section 51 indicates that the scope of application of the LRA actually covers all matters relating to divorce and other reliefs ancillary to the divorce such as custody and guardianship of children of the marriage which was registered under the Act, regardless of whether there is conversion by either party after the marriage.

The amendments also resulted in the insertion of a new provision of section 51A of Act 164, which empowers the court to make an order relating to the distribution of matrimonial properties in the event where the converting party died before the dissolution of the marriage. This distribution is basically made according to the nature and level of contribution of the parties in a marriage to the other party. In addition, this division will also include the rights of children in marriage, debts, and liabilities of the deceased as well as the rights of the deceased's parents. Although the issue of division of jointly acquired property is not affected by the conversion of one party, the addition of this new provision is actually intended to provide clarity on the power of the court as well as the rights of the interested parties in the event where the converting party had died before dissolution of marriage occurred.

\section{AMENDMENT TO SECTION 95 RELATING TO THE DURATION OF THE ORDER FOR THE MAINTENANCE OF CHILDREN}

The purpose of amendment to section 95 of the Act is to extend the duration of the order for maintenance of children where a child is pursuing his or her study further at a higher level or higher education or training. These amendments are made following the provisions of the law under the same section which previously merely gave the right to a child to get maintenance from his or her father until the child attained the age of 18 years or suffers from a physical or mental disability. Since the period of learning at the higher education started after 18 years, it will cause hardship to the children who are still studying after this age, as this requires a lot of expenses to pay their tuition fees as well as their cost of living. The matter has been raised 
in the case of Ching Seng Woah v Lim Shook Lin $^{12}$ in which the Court of Appeal had decided that the financial incapacity is also included in the meaning of physical disability. Therefore, the Court has ordered the father of the appellant to pay the tuition fees until his graduation at degree level.

The Court of Appeal in the case of Punithambigai a/p Ponniah $v$ Karunairajah a/l Rasiah has also applied the same principle. ${ }^{13}$ In this case, the father is made liable to pay his child's tuition fees up to the child's level of higher education. However, the above decision has been reversed at the Federal Court ${ }^{14}$ where the Court choose to use a literal interpretation and decided that financial inability is not included in the interpretation of physical disability.

The amendment to section 95 of Act 164 is also very important in clarifying the duties and responsibilities of a father towards his children particularly his responsibility in supporting his children who are still studying until the end of their higher education. It is hoped that, after graduation, the child would be able to find a job and support himself.

\section{AMENDMENT TO SECTION 76 AS TO THE ELEMENT OF CONTRIBUTIONS IN THE DIVISION OF MATRIMONIAL ASSETS AFTER DISSOLUTION OF MARRIAGE}

Amendment to section 76 of Act 164 shows the wider power of the court in the distribution of matrimonial properties. By virtue of this amendment, it eliminates the concept of matrimonial property contribution based on joint efforts or sole efforts of one of the parties in a marriage. This gives the opportunity to the court to make a broad assessment of the acquisition of matrimonial assets by both parties during their marriage. This is done by the court by applying the broadbrush principle. By this principle, the court will take into account any forms of contribution either directly or indirectly and this includes giving due recognition to the contributions made by the other party who

\footnotetext{
12 [1997] 1 MLJ 109.

13 [2003] 2 MLJ 529.

14 [2004] 2 MLJ 401.
} 
did not acquire the assets to the welfare of the family by looking after the home or caring for the family as a kind of work and can be adopted for the purpose of distribution of the matrimonial assets after their divorce. The duration of the marriage is also included as one of the factors that must be considered by the court for the purposes of equality of division of matrimonial assets.

Previously, prior to the amendment, ${ }^{15}$ if there is an application for division of matrimonial assets, the court will normally look at the extent of the contributions made by both parties in acquiring the assets. In making such assessment, the court will take into consideration whether the assets are acquired by joint efforts of both parties or acquired by sole effort of one party only. If both the husband and wife have contributed equally to the acquisition of the matrimonial property, then they are both entitled to equal division in which case both will get half division (1/2) of the property. However, if the contribution is only made by one party, then the other party who did not contribute will get less or generally one-third (1/3) of the total assets of the marriage. In most cases, a housewife who manages the affairs of the family by looking after the home and caring for the family will get less despite the fact that managing the household can also be considered as a kind of work. In other circumstances, a measure of the contribution is usually made in the form of financial or physical property and the same emphasis is not given for other forms of contributions of others such as labour or any form of sacrifices of a husband or wife to the welfare of the family, which is normally quite difficult to be assessed. As a result, the previous position in law is that a working mother who is also managing the household at the same time did not get due attention in law. ${ }^{16}$

Looking at the current situation in our society where both men and women are of the same standing in terms of their career, our family law should be made in line with social changes, and this justifies the

15 See the Law Reform (Marriage and Divorce) Act 1976, s.76.

16 See Norliah Ibrahim, "Masalah Tuntutan Harta Sepencharian "in Najibah Mohd Zin (ed) (2009), Siri Pengembangan Undang-Undang Keluarga Islam, Dewan Bahasa dan Pustaka, 2009, vol.14, 24. See also Noorul Huda Sahari, Division of Harta Sepencharian in the Malaysian Civil Courts; An Analysis of Judicial Approaches, (Thesis), Ahmad Ibrahim Kulliyyah of Laws, International Islamic University Malaysia, 2016. 
amendment. In other words, the law should be in line with the needs of society in meeting the current social needs and this includes the law on matrimonial property. Extensive involvement of women in various fields requires different evaluation so that the applicable law is capable to give justice to all parties, especially in maintaining the family welfare after the dissolution of the marriage or the death of one party. Precisely, the law related to the contribution should be extended by considering any kind of contribution of both husband and wife while they are still married. This matter has been referred to in the case of Yow Mee Lan $v$ Chen Kai Buan ${ }^{17}$ where the Singapore Court judges upheld that family life must be distinguished from other activities. The family life is based on the cooperation of both husband and wife in maintaining the wellbeing of the family according to their efforts and their respective capabilities. The difference in terms of effort and ability cannot be used as a reason to give them a different portion particularly if the contribution is made jointly for a continuous period of their marriage. The law in Singapore has adopted a wider principle to achieve fairness in the distribution of matrimonial assets by interpreting the concept of contribution in a wider context.

\section{DETERMINATION OF CHILD'S RELIGION IN THE CASE OF CONVERSION OF ONE PARTY TO A NON-MUSLIM MARRIAGE TO ISLAM}

In amending the Act, the most attractive and controversial issue is the issue of determining the child's religion in the case of conversion to Islam by one of the parties to a non-Muslim marriage. The first draft of the amendment bill has provided for the inclusion of new section $88 \mathrm{~A}$, which seeks to provide for the status of the religion of a child in the event of conversion of either spouse to Islam. The said provision reads as follows:

S.88A.

(1) Where a party to a marriage has converted to Islam, the religion of any child of the marriage shall remain as the religion of the parties to the marriage prior to the conversion, except where both parties to the marriage agree to a conversion of the child to Islam,

17 [2004] 4 SLR 466 (Singapore case). 
subject always to the wishes of the child where he or she has attained the age of eighteen years.

(2) Where the parties to the marriage professed different religions prior to the conversion of one spouse to Islam, a child of the marriage shall be at liberty to remain in the religion of either one of the prior religions of the parties before the conversion to Islam.

However, the inclusion of this additional section was withdrawn due to a legal position that puts the child's religious status to remain status quo as before the dissolution of marriage until the child reaches the age of 18 years in which age, they have the right to choose their own religion. An exemption is granted if both parents agree for the child's conversion to Islam.

This approach, if adopted would be contrary to the principles of the welfare or the best interest of the child as contained in the Convention on the Rights of the Child and the laws that apply in determining the custody of children after divorce. Basically, the court shall determine the right of custody of children under the age of 18 years after the divorce through the court's order unless there is consent and agreement of both parents on the custody of children subject always to the principle of safeguarding the welfare and best interest of the child. The main constraint in our existing law is to address the issue of unilateral conversion of a minor child to Islam by the converting parent without the knowledge and consent of the other parent and this has caused dissatisfaction and injustice to the non-converted parents. ${ }^{18}$ Normally, the argument would be based on the provisions in Article 12(4) of the Federal Constitution which by its wording, provides that the religion of a person under the age of 18 years shall be decided by his parent or guardian. This means that either father or mother has the right to determine the child's religion, and this includes converting the child to Islam without having to get the consent of the other parent. In

18 See cases; Genga Devi a/p Chelliah v Santanam a/l Damodaram (2001) 1 MLJ 526; Chang Ah Mee v Jabatan Hal Ehwal Agama Islam, Majlis Ugama Islam Sabah \& Ors, 20035 MLJ 106; Nedunchelian v Uthiradam $v$ Nurshafiqah Mah Singai Annal \& Ors (2005) 2 CLJ 306; Shamala Sathiyaseelan v Dr. Jeyaganesh C Mogarajah (2004) 3 CLJ 516; Subashini Rajasingam $v$ Saravanan Thangathoray \& Other Appeals (2008) 2 CLJ 1. 
the case of Subashini Rajasingam v. Saravanan Thangathoray \& Other Appeals, the Federal Court took a literal approach in interpreting the word 'parent' in Article 12(4) of the Federal Constitution to mean a single parent and subsequently held that either husband or wife has the right to convert a child of the marriage to Islam. Undoubtedly, for normal families, this provision shall not give any problems. However, the question now is whether this provision can be applied in the situation where the children of the marriage are still underage, and their parents are already divorced.

Determination of the religion of a child in the case of divorce should also take into account the legal provisions under the family law that gives the right to determine the welfare of the child in terms of upbringing and education to the person who gets the custodial right and this includes the spiritual needs or religious upbringing of the child. ${ }^{19}$ It is therefore reasonable in the case of custody disputes involving parents of a different religion that any person who has been given the right of custody shall also have the right to determine the child's religious upbringing. To put the custodian and his or her child in a situation of different religions is not something, which is practical, and in fact, this can trigger confusion to the child and would have an adverse effect to the child's development. This approach has also been decided in the case of Strum v Strum where the court held that in determining the religion of children involving interfaith parents, it is not the power of a court to decide such matters, but it is up to the party who has the right of custody of children to determine it. ${ }^{20}$ The court, in this case, applied the principles of humanity in understanding current reality involving a relationship between parents and children.

This principle can also be adopted in Islamic law where there are different views of the Muslim scholars relating to the rights of child's custody after divorce in the case where it involves parents of a different

19 See the Law Reform (Marriage and Divorce) Act 1976, s.88(2) and s.89(1).

20 See Strum v Strum (1969) 14 F.L.R 284. Quoted in Mehrun Siraj and Haji Sulaiman Abdullah, 'Islamic law and Civil law in Malaysia: Constitutional Confusion and Curial Curiosities', this article was published by INSAF, $9^{\text {th }}$ Malaysian Law Conference, 10-12 Oct 1991, Kuala Lumpur Malaysia. 
religion. ${ }^{21}$ In search of the best solution, paramount consideration should be given to the principle of the welfare of children or the best interest of the child as a guide for the court in determining the custody and thus determine the religious upbringing of children. This is because the factor of religion is not the sole factor to be considered in determining custody in case of a conflict involving interfaith parties when they are unable to resolve their case through mutual consent. The said approach does not require amendments to any laws, particularly the Federal Constitution. This is because in the case of divorce, only one party will be ordered by the court to take the responsibility of caring for the child and keeping his or her welfare. It is both parents that must take their responsibility in giving affection to their children irrespective of religious differences or restrictions.

\section{DISCUSSION AND CONCLUSION}

Amendments to the Act 164 can be seen as an effort that has been done by the Government as an action to the recommendations that have been proposed over the years in solving the conflict of jurisdiction between the Syariah and the civil court. What is important is that it gives the opportunity to both parties to the conflict to resolve their disputes through a forum only and this will enable the court to make orders related to the dissolution of the marriage such as maintenance, division of matrimonial assets and custody of children.

Under the Malaysian legislation, a Muslim is not allowed to marry a non-Muslim and when one party to a non-Muslim marriage converts to Islam, it will be a ground to dissolve the marriage. By reason of this amendment, the principles of one court would be applicable to the parties and thus, would enable them to find the best solution including resorting to mediation in resolving issues in family

21 See Mohd Zin, N., 2012. Legal Disputes in Determining the Religion of the Child when one Parent Converts to Islam under Malaysian Law. Australian Journal of Basic Applied Sciences, 6(11): 66-73; Ibn Qudamah, Al Mughni, wa al Sharh al Kabeer, Vol.10, Dar al Kutub al Arabi, p. 96. See also Badran Abu al Ainaini Badran, Al Alaqah al Ijtimaiyyah baina al-Muslimin wa Ghairi al Muslimin, Dar al Nahdhah al Arabiyyah, p.165. 
conflict. Moreover, it also gives an opportunity to the court to develop more legal principles, whether in terms of civil and Syariah and broadens the approach to harmonization of law in matters involving the conflict of religion. Although the amendment has succeeded in resolving the issue of jurisdictional conflict between the civil and Syariah courts, it should be noted that the conflict relating to the determination of the religion of a child in a custody dispute involving interfaith parents still exists and it needs to be tackled by the court wisely with the best interest of the child as a paramount consideration. 